\title{
URGENCY OF CONTENT VILLAGE REGULATION IN THE FRAMEWORK OF VILLAGE GOVERNANCE
}

\author{
Ali Rido \\ Universitas Trisakti, \\ Faculty of Law \\ Jl. Kyai Tapa No. 01, Grogol Jakarta Barat. \\ Correspondence Email : alirido@trisaksti.ac.id
}

\begin{abstract}
Village regulations, as part of the rules, must-have content material if they are to be established. In higher principles, the content of village regulations is not explicitly regulated but only explains the macro aspects of village authority. Given that the content material is not in detail, it is crucial to reinforce the content of village regulations as a guide in its formation. Through normative juridical research that uses a statutory and conceptual approach, the results found two critical things. First, affirming the content of village regulations becomes very important considering that the village government regime has the authority to form village regulations, which are a type of statutory law as is familiar with other statutory regulations. Second, the content of village regulations can be emphasized and detailed by looking at the authority of the village. Thus, the content materials used as guidelines in the formation of village regulations are as follows: 1). The content relating to the rights of origin of the village; 2). Material content about the value of local villages; 3 ). The content material, which is the duty of the government, is following the provisions of laws and regulations.
\end{abstract}

KEYWORDS: Village regulations, Content Material, and Government

\section{INTRODUCTION}

One that emerged after the promulgation of Law Number 6 of 2016 concerning Villages (from now on referred to as the Village Law) is the existence of village regulations as an instrument for implementing village governance (Jacqueline et al., 2017; van Rooyen, 2016). The presence of a quo Law has triggered exoticism in the discussion of village regulations, which initially were only recognized as a type of legislation and were discussed at a minimum in the constitutional spectrum. With the presence of a particular law (lex specialist) regulating villages, village regulations are not only a village legal instrument but a basis for village development. Its existence must be seen as an inherent part of construction like other regulations, such as local laws and regulations.(Asshiddiqie, 2010; Neyasyah, 2019; Prasojo, 2015) Why is that? Then it can be answered by tracing the concept of the Rule of Law and Law as a development tool.

The essence in the rule of law is that the main factor in the implementation of state activities (such as development) must first have a legal umbrella so that its 
implementation does not deviate from legal corridors.(Sujana, 2016; Usman, 2015) Therefore, the President, as the executive, works based on the orders of the 1945 Constitution of the Republic of Indonesia, the law and its implementing regulations. (Azhary, 1995) About the law as a development tool that all developing societies are always characterized by change, and the law functions as a guarantor for that change to occur in an orderly manner. (Atmasasmita, 2016) Likewise, village regulation, the lowest rule in the hierarchy of statutory rules can be positioned into two things; 1) as a way for the success of development at the village level so that it is following higher laws and regulations; 2) transforming the thoughts, will, and consensus of a dynamic village community into order.(Al-Arif, 2017; Nurjaman \& Prasetyo, 2018)

The above construction can be traced by linking the definition of village regulations and village development as stipulated in the Village Law. (Roza \& Arliman, 2017; Wuisang, 2018) The provisions of Article 1 point 7 of the Village Law state; Village Regulations are statutory regulations specified by the Village Head after being discussed and agreed upon with the Village Consultative Body. Then in Article 1, number 8 is mentioned; Village Development is an effort to improve the quality of life and life for the maximum welfare of the Village community. From these two definitions, it can be interpreted that the village head as the representative of the village community who is directly elected by the city has the task of carrying out village development. To ensure the success of village development, the village head is given the authority to establish village regulations as the legal basis for growth.

The content material can also interpret the definition of village development above in village regulations regarding efforts to improve the quality of life and life, which are projected for the maximum welfare of the village community. As a rule, a guideline for content material must be determined, especially when village regulations are the 'lowest type of regulation' in the hierarchy of statutory provisions (from now on referred to as PUU) so that patenting the content is a necessity if you look at Law Number 12 of 2011 jo. Law Number 15 of 2019 concerning the Formation of Legislative Regulations (from now on referred to as the P3 Law), then for regulations that regulate exit or bind the material content has been determined. These types of rules include, among others, laws/government regulations instead of laws, government regulations, administrative regulations, provincial regulations, and district/city regional regulations.

As an example for the content of the law, Article 10 paragraph (1) of the P3 Law states that the content that must be regulated by statute contains:

1. further regulation regarding the provisions of the 1945 Constitution of the Republic of Indonesia;

2. order of law to be regulated by law;

3. ratification of certain international treaties;

4. the follow-up to the decision of the Constitutional Court; and

5. fulfillment of legal needs in society.

Meanwhile, for the content of regional regulations, Article 14 of the P3 Law states that the material for the content of provincial rules and district/city local 
regulations contains material in the context of implementing regional autonomy and assistance tasks as well as accommodating special regional conditions and further elaboration of higher laws and regulations.

Village regulations also have the same spirit, namely binding rules, even though they are only limited to the scope of the village community. Because they have similarities, detailing the content of village regulations is a necessity considering that the P3 Law does not explain the content of the village regulations. Also, the two examples of regulatory content above, seem to be explicitly determined to form rules according to needs so that the direction of development at each level of government can be achieved perfectly. Another goal is not to bump into regulations that are vertical and do not overlap with horizontal rules. On that basis, it is important for this type of village regulation to emphasize its content in order to support the optimization of development in the village. Another reason is that village regulations are prohibited from contradicting public interests or the provisions of higher legislations. Therefore, formulating the content material becomes essential to prevent precedents from conflicting village regulations with public affairs and more top regulations.

Another urgency is to trace the definition of the content itself. Content is material contained in statutory regulations following the type, function, and hierarchy of statutory provisions. Based on this definition and by linking it to the construction of Article 8 paragraph (1) of the P3 Law, it is increasingly important that the scope and details of the contents of the village regulation must be determined and emphasized. This is because Village regulations are a type of PUU that is not only recognized by the Village Law but also by the P3 Law, which is the main guideline for the formation of statutory regulations in Indonesia.

Based on the above circumstances, the explanation in this paper will present the direction of the content of village regulations as a village legal instrument. The affirmation of the content of village regulations is intended so that the formation of village regulations is in line with the construction of the formation of logical regulations and meets the needs of the community so that the mission of village development can be realized. A more critical aspect is that village regulations have a more legitimate legal binding power and do not conflict with higher laws and do not override existing rules.

\section{METHODOLOGY}

This research is a type of normative juridical research, which is a study or research that emphasizes more on the analysis of written legal norms and literature. The data used in this study uses secondary data consisting of:

1. Primary legal materials are consisting of statutory regulations, such as Law Number 12 of 2011 jo. Law Number 15 of 2019 concerning the Formation of Legislations, Law Number 6 of 2014 concerning Villages, and other related laws and regulations. Apart from that, it also refers to official records or minutes in the formation of the associated laws; and 
2. Secondary legal materials, which include textbooks and legal journals.

The data collection technique used is library research, which is carried out by collecting, reading, analyzing, classifying, and reviewing, as well as criticizing the provisions of laws and regulations, books, and related journals. Apart from that, there is also reading and studying the doctrines and opinions of experts as well as the results of research.

Concerning the analysis, the collected materials were analyzed using qualitative methods. This analysis places more emphasis on the in-depth understanding of a problem with the aim that research can produce detailed descriptive data (detailed analysis). (Hamidi, 2004)The data analysis technique used in this study is content analysis, namely by analyzing various sources of data that have been obtained. The approach used is a statutory approach (statute approach) and a conceptual approach (conceptual approach). The regulatory procedure is carried out by examining all laws and regulations related to the legal issue being studied. Meanwhile, a conceptual approach is used to develop the concept of the direction of the content of the village regulations.

\section{RESULTS AND DISCUSSION}

1. Village Government Regime and the Importance of Village Regulations

Article 8 paragraph (1) of the P3 Law does not explicitly state the position of village regulations, but only mentions types of village head regulations or equivalent. The absence of the term "Village Regulation" in the PPP Law reminds us of the same situation in the New Order era, wherein the authoritarian age the time "Village Regulation" was not known but only known as "Village Decree" as regulated in Article 18 of Law no. 5 of 1979. The provisions of Article 18 stipulate that the Village Head shall determine a Village Decree after deliberation/consensus with the Village Deliberative Council. With the formulation of Article 18 of Law no. 5 of 1979, the village decision is determined after a deliberation mechanism is held in the village between the Village Head and the Village Deliberative Council.(Simanjuntak, 2016)

Even so, with the issuance of the Village Law, village regulations as a product of village law have a stronger and clearer position as well as an answer to doubts about whether village regulations can be categorized as a type of PUU. The strengthening and clarity of the intended village regulations can at least be traced in the provisions of Article 69 and Article 70 of the Village Law. The two articles regulate, among others: types of village regulations, the process of forming village regulations. In fact, the provisions of Article 110 of the Village Law also introduce the term customary village regulation. The current village regulation, its position is adjusted to the customary law and usual norms that apply in the traditional village as long as it does not conflict with the provisions of the statutory regulations. In 
addition to the inauguration of village regulations as a legal product, the Village Law also brings the winds of change to the village government regime.(Jimly, 2002)

In addition to providing strengthening and affirming the position of village regulations, the Village Law also labels the village government regime. This label is undoubtedly different from the regional government regime, why is that? The minimal answer to this can be traced through Law Number 23 of 2014 jo. Law Number 9 of 2015 concerning Regional Government (from now on referred to as the Regional Government Law). Article 57 of the Regional Government Law states; provincial and regency/city regional governments consist of regional heads and DPRD assisted by Regional Apparatus. Furthermore, Article 209 paragraph (1) and paragraph (2) states:

a. Provincial apparatus consists of:

1) The regional Secretariat;

2) DPRD Secretariat;

3) inspectorate;

4) service; and

5) Body;

b. District/city regional apparatus consists of:

1) The local Secretariat;

2) DPRD Secretariat;

3) Inspectorate;

4) Service;

5) Body; and

6) Sub-district.

Construction of the article above, it can be read that the hierarchy in local government stops only at the sub-district level. Meanwhile, the position of the village government, in the construction of the Unitary State of the Republic of Indonesia, is recognized and protected because it has local values even though it is not designed in a regional government hierarchy. Based on these reasons, the consequence is that village regulations should not only be seen as a local government regime but as a new government regime, namely the village government. The new government regime, it seems logical if you look at Asshiddiqie's view which states that the existence of villages as 'self-governing communities' is autonomous or independent so that it brings consequences that the organic reach of state organizations only reaches the sub-district level. In contrast, under the sub-district, it is considered an autonomous region that is the regulation and guidance are left to the dynamics that live in the community itself autonomously.

Even though it is no longer a regional government regime and the P3 Law has separated village regulations from part of regional regulations, village regulations still have an important position because they are a product of government administration in the context of carrying out regelling government functions. As explained by Bagir Manan, the government is the holder of power or executor of 
the duties and authorities of state administration. State administration as a government function has two responsibilities and authorities, namely carrying out the tasks of judicial administration (uitvoering) and making regulations to carry out government functions (regelling). (Manan, 2001)The village government is a regime that is recognized in the Indonesian government system in which the village head is led as the holder of power. One of the village heads, which is the holder of power at the village level, is given the authority to form village regulations with the Village Consultative Body (from now on referred to as BPD).

The position of the village head as a government official (ambtsdrager) at the village level has implications for him regarding the obligation to carry out the function of regulating government. The manifestation of carrying out government regulatory functions is through village regulations and village head regulations. For this reason, village regulations are a product of "state administration" because they are formed by the power holders (regional heads and BPD). Thus, although the P3 Law has repositioned the position of village regulations, its existence is still essential as a tool in the implementation of village governance.

Another essential dimension of the existence of village regulations can be seen from the conception of the Indonesian constitutional state as stipulated in Article 1 paragraph (3) of the 1945 Constitution of the Republic of Indonesia. As the rule of law, all life as a state must be based on code (rechstaat), not on sheer power (machstaat). Burgens expressed the definition of rechtstaat, namely a nation that places law as the basis of state power, and the exercise of this power in all its forms is carried out under the rule of law. (Attamimi, 1992) Such provisions also apply in the life of the village government, where every action of the village government must be based on legal and written regulations. This means that statutory and written rules must be in place before any administrative action or action is carried out by the village government.(Qomar, 2010; Satjipto, 2006)

Based on the description above, even though the village government regime has experienced a shift, which implies a change in the position of village regulations, the existence of village regulations as an instrument of government administration is still needed. Therefore, affirming the material direction of the content has the same importance as the manifestation of the principles of a democratic rule of law. (Indrati \& Farida, 2007) The affirmation of the direction of the content of the village regulation, of course, is based on the reading of the village authority that has been regulated through the Village Law because it is the main as well as the special regulations in the current village administration.

2. The direction of Village Regulation Content Material

Another essential part of a rule is the existence of content material, and it can even be said that the material content becomes the spirit of the regulation itself. Therefore, each law that has a hierarchical level in PUU is almost sure to have substance. Likewise, for village regulations, it is essential to determine the content material. As explained above, the village government regime has undergone a shift by no longer positioning the village as part of the regional government, but the town still has governmental authority. Because of the different positions, it affects the content material in the village regulation itself. 
Even so, the Village Law has not actually carried out a thorough exploration of the contents of the village regulation. The scope of village regulations, only implicitly if they read related to village authority. For this reason, it is essential to conduct further studies to reinforce and clarify the content of village regulations. The scope of the material content of the village regulations can be seen in the existence of Article 19 and Article 67 paragraph (1) letter a of the Village Law which in principle states the village authority includes:
a. authority based on rights of origin;
b. Village scale local authorities;
c. Authority assigned by the Government, Provincial Government, or Regency / City Government; and
d. other authorities designated by the Government, Provincial Government, or Regency / City Government in accordance with PUU provisions.

From the construction of Article 19 and Article 67 paragraph (1) of the Village Law, there are 3 (three) main elements that can be described as references to the material for the content of the Village Regulation as follows:

1) Content relating to village rights of origin

Authority based on the right of the origin is a right which is a living inheritance and a village initiative or village community initiative following the development of community life. In this definition, it can be explained that the domain of village government under its authority must be based on the initiative of the village community to accommodate the dynamics that occur in the life of the village community. However, accommodation for the development of life in question must still pay attention to the authenticity (origin) of a village so that it can represent the originality of a town.

In the regulation, the definition of the village is divided into 2 (two), namely 'ordinary' village and customary village. However, both have the same authority, namely, about the rights of origin of the town. Because they have the same power, in determining the content of village regulations for 'ordinary' hamlets and customary villages, of course, they will not be much different as long as the guidelines are based on indigenous rights that arise from the initiative of the village concerned and the initiative of the local community and throughout does not conflict with the provisions of the applicable laws and regulations.

In this regard, the contents that can be explored based on the village's right of origin are as follows; first, the management of original assets within the village jurisdiction. Control of the said assets, of course, must be related to the following 2 (two) things:

a) Assets that must be and will be regulated concerning assets that have village origins or have links to the history of the source of the village's formation;

b) Assets that must and will be regulated do not exceed the boundaries of a village. 
The two boundary lines must be used as a reference in mapping arrangements regarding village asset management so that they are in line with the principles of recognition and diversity.

As for what can be concretized as material for village regulations regarding asset management, including regarding:(Amelia, 2015; Harsono, 2003; Sembiring, 2016)

1. Provision of natural resources owned by the village;

2. Regulating communal land in a community;

3. Arrangements regarding village treasury lands or village-owned land using local designations;

4. Arrangements regarding bent soil;

5. Regulation regarding pecatu area; and

6. Regulations regarding titisara soil. Some of these concrete guidelines can become content materials that can be regulated by village regulations because they are following the details directed by higher legislation.

Second, the formation of a village government structure by accommodating the original arrangement. The aspect of originality or the fundamental rights of a village in this context remains an integral part. This is because the power of origin is a reflection of an inheritance that is still alive following the life of the village community. Therefore, in dealing with the content related to the formation of the village government structure, it must accommodate the original village composition. In this context, what can be concretized and as an example in the content material are as follows:

a. Arrangements related to the organizational system of village apparatus;

b. Arrangements associated with the conventional community organization system;

c. arrangements related to the structuring of the customary community organization and institutional system;

d. Arrangements associated with filling the positions of the traditional village head and regular village officials, and

e. Arrangements related to the tenure of the customary village head.

Third, disputes over customs and preservation of local traditions and culture. This aspect gives recognition to the village that problems in the town are not necessarily identical to be resolved through formal legal channels. However, issues in the city can be resolved through non-formal-legalistic mechanisms such as through deliberations guided by the principle of kinship. For this reason, content material that can be used as a reference in a village regulation can include the following:

a. arrangements regarding village customary institutions and laws. In this aspect, village institutions can be designed in accordance with the spirit of the village community as a house for solving various legal problems that arise in the life of the village community;

b. regulations regarding community legal institutions. In this aspect, it is aimed at establishing legal institutions for 'ordinary' village communities. 
For this reason, village regulations can include content that determines which legal institutions can be used as a reference by the community. Apart from the institution, it can also regulate related to the implementer so that the institution (institution) can be run as a medium for village community participation as a partner in the village government.

The direction of the material above, if you want to transform it into a village regulation, must depart from the initiative of the village community. This is a form of giving the broadest possible opportunity to the village so that they can run the wheels of government democratically. With the initiative of the village community, it confirms the essence of democracy from, by, and for the people to be fully returned to the concept of village governance. Thus, it is very appropriate if the formation of village regulations has a spirit of democratizing the village and advocating for democracy.

2) Content relating to the value of local villages

Before entering into the core content regarding the local values of the village, it is essential to look at the substance contained in Article 1 point 4 of the Regulation of the Minister for Rural Development, Disadvantaged Areas and Transmigration Number 1 of 2015 (from now on referred to as Permendes PDTT) which states:

The village-scale local authority is the authority to regulate and manage the interests of the Village community that have been carried out by the village or are capable of and effectively carried out by the town or that have emerged due to Village developments and Village community initiatives.

It can be said that the provisions regarding village-scale local authority constitute a new authority that takes into account the legal, political director of the village administration towards genuine autonomy. Original autonomy, namely having the power for the village government in regulating and managing the interests of the local community based on the rights of origin and social values that exist in the local community. However, it must be held in the perspective of modern government administration.(Kusnadi, 2015)

Then in Article 5 Pemendes PDTT No. 1 of 2015 states that the criteria for village-scale local authority include:

a) Power that prioritizes community service and empowerment activities;

b) The power that has the scope of regulation and activities only within the village area and community that has an internal village impact;

c) Authority relating to the daily needs and interests of the village community;

d) Activities that have been carried out by the village based on village initiatives;

e) Program activities of the government, provincial government, and district/city governments and third parties that have been submitted and managed by the village; and 
f) Village-scale local authorities that have been regulated in the statutory regulations concerning the division of power of the government, provincial government and district/city government.

Departing from the explanation of village-scale local authority above, the essence of the content material that can be guided in the village regulation can include the following aspects: first, content material related to service activities and community empowerment, such as empowerment in the fields of education, economy, tourism, technology, religion, and the like. Second, the content related to the primary life needs of the community, such as the development of the village economy for the benefit of the village community, the use of village funds for the fulfillment of clothing, food, and housing for poor rural communities. Third, following up on government programs, such as the implementation of village management, which is the affairs of the district/city government.

3) Content which is the duty of the government following the provisions of laws and regulations

An outline to be used as content material for village regulations, which are the duties of the government following the Draft Law, of course, by waiting first what tasks are given by the government (both central and provincial and district/city). In such a spectrum, the functions delegated to the village can be in the form of attribution and delegation of authority. Concerning delegation of power, it includes commissions and mandates. Some of these types of power can be used as content when the government has given it to the village. Thus, in principle, the village government is waiting for an assignment from the government.

Even so, if traced in the provisions of the Draft Law as in the attachment to Law Number 23 of 2014 jo. Law Number 9 of 2015 concerning the Regional Government, the tasks that can be given to villages can be identified through government affairs. Some of the content materials that can be used as guidelines in village regulations based on the duties of the government, both central and local governments, are as follows:

a) Responsibilities of the government about education;

b) Responsibilities of the government regarding health;

c) Responsibilities of the government related to public works and spatial planning;

d) Responsibilities of the government about housing and settlement areas;

e) The duties of the government concerning public order and order and protection of the public;

f) Responsibilities of the government concerning social;

g) Responsibilities of the government concerning human resources;

h) Obligations of the government concerning empowering women and protecting children;

i) Responsibilities of the government regarding food;

j) Duties of the government concerning land; 
k) Obligations of the government concerning the environment;

l) Responsibilities of the government relating to population administration and civil registration;

m) Duties of the government regarding control of occupation and family planning;

n) Obligations of the government concerning communication and informatics;

o) Responsibilities of the government regarding cooperatives, small and medium enterprises;

p) Responsibilities of the government concerning youth and sports;

q) Responsibilities of the government concerning culture;

r) Responsibilities of the government regarding libraries;

s) Responsibilities of the government relating to tourism;

t) Responsibilities of the government about agriculture; and

u) Responsibilities of the government about forestry.

The task of the government, as mentioned above, if the government is assigned to the village to help it, it can be followed up with a village regulation. Thus, the content of the village regulations in this regard is only to follow up on what is assigned by the government. In other words, the content of the village regulation must not go outside the line of duties that the government has attached. This means that the village government must not precede the preparation of the content of the village regulations without any assignments or orders from the government.

\section{CONCLUSION}

The content in a Draft Law is an essential element. It can even be said to be the spirit of regulation. Therefore, village regulations, which are a type of Draft Law, must also have content material. In terms of vertical rules, the content of village regulations has been touched on to some extent, but its nature is only on the macro aspect of the scope of village authority. Starting from the power possessed by the village, it is essential to describe it comprehensively so that it can be used as material for village regulations. An important reason why the content of the village regulation must be emphasized is that the village government regime has received powerful legitimacy. The existence of the Village Law has positioned the village as a government regime, although it is no longer the domain of the regional government regime. At the same time, the village government is given the authority to form village legal products, one of which is the village regulation.

Having the authority to form the legal instrument in question, it is essential to clarify the content of the material so that it becomes a guideline in the formation of village regulations. The aim is none other than so that in the formation of village regulations, they do not deviate from the authority that has been given by higher legislation. With regard to the emphasized content material, it is by mapping and detailing (breakdown) of the power owned by the village. From this authority, content materials that can be used as guidelines in the formation of village 
regulations can be specified as follows: 1). The content relating to the rights of origin of the village; 2). Material content pertaining to the value of local communities; 3). The content material, which is the duty of the government, is following the provisions of laws and regulations.

\section{Referencces}

Al-Arif, M. Y. (2017). Problematika Hukum Pengaturan Desa Dalam Konstitusi (Analisis Terhadap Pengaturan Desa Sebelum dan Sesudah Perubahan UUD NRI 1945) [PhD Thesis]. Universitas Islam Indonesia.

Amelia, M. (2015). EKSISTENSI TANAH PECATU DI KABUPATEN LOMBOK TIMUR (Studi Kasus Di Desa Sukadana Kec. Terara Kab. Lombok Timur). Jurnal IUS Kajian Hukum Dan Keadilan, 3(2).

Asshiddiqie, J. (2010). Konstitusi masyarakat desa (piagam tanggungjawab dan hak asasi warga desa). Tersedia:(Http://Jimly. Com/Makalah/Namafil e/176/KONSTITUSI_MASYARA KAT DESA. Pdf).

Atmasasmita, R. (2016). Tiga Paradigma Hukum dalam Pembangunan Nasional. Jurnal Hukum Prioris, 3(1), 1-26.

Attamimi, A. H. S. (1992). Teori perundang-undangan indonesia: Suatu sisi ilmu pengetahuan perundang-undangan Indonesia yang menjelaskan dan menjernihkan pemahaman. UI-Press.

Azhary. (1995). Negara hukum Indonesia: Analisis yuridis normatif tentang unsurunsurnya. Penerbit Universitas Indonesia.

Hamidi, A. (2004). Metode Penelitian Kualitatif: Aplikasi Praktis Pembuatan Proposal dan Laporan Penelitian Malang. UMM Press.

Harsono, B. (2003). Hukum Agraria Indonesia, Sejarah Pembentukan UUPA, Isi dan Pelaksanaannya. Jilid I Hukum Tanah Nasional, Cetakan Kesembilan (Edisi Revisi). Jakarta: Djambatan.

Indrati, M. F., \& Farida, M. (2007). Ilmu Perundang-Undangan: Jenis, Fungsi dan Materi Muatan. Yogyakarta: Kanisius.

Jacqueline, V. E. L., Zakaria, Y., \& Bedner, A. (2017). Law-making as a strategy for change: Indonesia's new Village Law. Asian Journal of Law and Society, 4(2), 447-471.

Jimly, A. (2002). Konsolidasi Naskah UUD 1945 Setelah Perubahan Keempat. Pusat Studi Hukum Tata Negara, Fakultas Hukum, UI. Jkt.

Kusnadi, A. (2015). Perkembangan Politik Hukum Pemerintahan Desa Menurut Undang-Undang Nomor 32 Tahun 2004 tentang Pemerintahan Daerah dan Undang-Undang Nomor 6 Tahun 2014 tentang Desa. Padjadjaran Journal of Law, 2(3), 564-580.

Manan, B. (2001). Menyongsong fajar otonomi daerah. Pusat Studi Hukum, Fakultas Hukum, Universitas Islam Indonesia. 
Neyasyah, M. S. (2019). Keberlakuan Yuridis Peraturan Desa Dalam Perspektif Asas Formal Kelembagaan Pembentukan Peraturan Perundang-Undangan. University Of Bengkulu Law Journal, 4(1), 19-34.

Nurjaman, R., \& Prasetyo, A. G. (2018). Desa dalam Administrasi Publik Indonesia Kontemporer: Penguatan Peran LAN. Jurnal Borneo Administrator, 14(1), 3552.

Prasojo, R. A. (2015). PERAN PEMERINTAH-MASYARAKAT DALAM PEMBANGUNAN DESA (Studi di Desa Sedatigede Kecamatan Sedati Kabupaten Sidoarjo) [PhD Thesis]. UNIVERSITAS MUHAMMADIYAH SIDOARJO.

Qomar, N. (2010). Perbandingan Sistem Hukum dan Peradilan Civil Law System dan Common Law System. Pustaka Refleksi.

Roza, D., \& Arliman, L. (2017). Peran Badan Permusyawaratan Desa di Dalam Pembangunan Desa dan Pengawasan Keuangan Desa. Padjadjaran Journal of Law, 4(3), 606-624.

Satjipto, R. (2006). Ilmu Hukum. Bandung, PT. Citra Aditya Bakti.

Sembiring, J. (2016). Tanah negara. Prenadamedia Group.

Simanjuntak, E. (2016). Pengujian Perda dan Perdes Pasca Perubahan UU Pemda dan UU Desa. Jurnal Konstitusi, 13(3), 639-656.

Sujana, I. G. (2016). Eksistensi Politik Hukum Perundang-Undangan Dalam Sistem Ketatanegaraan Republik Indonesia. Widya Accarya, 5(1).

Usman, A. H. (2015). Kesadaran Hukum masyarakat dan Pemerintah sebagai Faktor Tegaknya Negara Hukum di Indonesia. Jurnal Wawasan Yuridika, 30(1), 2653.

van Rooyen, P. P. (2016). Management of retirement housing schemes in terms of the South African law considered with reference to the New South Wales retirement village law.

Wuisang, A. (2018). Reposisi Peraturan Desa Dalam Hierarki Perundang-Undangan. PAKUAN LAW REVIEW, 4(1). 